\section{Quantitative Separation of Calcium, Barium and Phosphate}

Quantitative Trennung von Calcium, Barium und Phosphat

T. S. B. NARASARAJU and V. L. N. RaO

Department of Chemistry, Banaras Hindu University, Varanasi, India

Received December 7, 1971

A quantitative separation of calcium, barium and phosphate was required in the course of physicochemical investigations on synthetic solid solutions of calcium and barium hydroxylapatites. The present work has been an attempt to arrive at optimum conditions for the purpose.

Barium was first separated as chromate and from the filtrate calcium and phosphate were determined by a modification of Washburn and Shear's method $[1,3]$.

Convenient amounts of barium chloride, calcium carbonate and potassium dihydrogen phosphate were dissolved in hydrochloric acid (sp. gr. 1.18) and diluted to about $100 \mathrm{ml}$, eare being taken to drive out by slight warming the evolved carbon dioxide. About $10 \mathrm{ml}$ of $10 \%$ potassium chromate solution were then added followed by the dropwise addition of about $1 \mathrm{M}$ ammonium hydroxide till the $\mathrm{pH}$ was found to range between 4 and 6 as scrutinised by a $\mathrm{pH}$ meter. The completion of the precipitation was confirmed by further addition of a few drops of potassium chromate solution. The precipitate was filtered through a weighed 1G4 crucible, washed with about $0.5 \%$ ammonium acetate solution till the washings were free from calcium and phosphate, dried to constant weight at $120^{\circ} \mathrm{C}$ and weighed.

Calcium and phosphate were determined from the filtrate by the method mentioned above [3] with the following modifications: (1) Addition of thymol blue was avoided since its colour change got masked by the chromate ions. (2) Attainment of appropriate $\mathrm{pH}$ values required for the precipitation of calcium oxalate and magnesium ammonium phosphate ( 7 and $10-12$, respectively) was scrutinised by using a $\mathrm{pH}$ meter. The precipitates were dissolved in about $6 \mathrm{M}$ hydrochloric acid and their calcium and magnesium contents determined complexometrically [2].

In the analysis of synthetic mixtures containing $67-112 \mathrm{mg}$ of $\mathrm{Ca}, 61-131 \mathrm{mg}$ of $\mathrm{Ba}$ and $23-30 \mathrm{mg}$ of $\mathrm{P}$ the errors obtained were in the range of $0.6-1.8$, $0-1.5$ and $0.1-0.4 \mathrm{mg}$, respectively.

When the method was applied to $0.3456 \mathrm{~g}$ of a synthetic solid solution of calcium and barium hydroxylapatites $\left[\mathrm{Ca}_{10}\left(\mathrm{PO}_{4}\right)_{6}(\mathrm{OH})_{2}+\mathrm{Ba}_{10}\left(\mathrm{PO}_{4}\right)_{6}\right.$ $(\mathrm{OH})_{2}$ ] the weights found were: calcium, $0.0257 \mathrm{~g}$; barium, $0.1956 \mathrm{~g}$; and phosphorus, $0.0419 \mathrm{~g}$; which gave a $\mathrm{g}$ atomic ratio, $(\mathrm{Ca}+\mathrm{Ba}) / \mathrm{P}$, equal to 1.66 (theoretical value, 1.67).
We thank Professor G. B. Singh, Head, Chemistry Department, Banaras Hindu University, for encouragement and provision of facilities and the UGC (India) for financial assistance given to one of us (VLNR).

\section{References}

1. Chickerur, N. S., and Narasaraju, T. S. B.: Analyst 98, 344 (1968); cf. Z. Anal. Chem. 244, 324 (1969).

2. Singh, R. P., Chickerur, N. S., and Narasaraju, T. S. B.: Z. Anal. Chem. 237, 117 (1968).

3. Washburn, M. L., and Shear, M. J.: J. Biol. Chem. 99, $21(1932 / 33)$.

Dr. T. S. B. Narasaraju

Faculty of Science

Banaras Hindu University

Varanasi-5, India

\section{3-Nitroso-4-hydroxycoumarin as Indicator for the Titration of Iron(III) with EDTA}

3-Nitroso-4-hydroxycumarin als Indicator für die Titration von Eisen(III) mit ÄDTA

\section{G. Singh MankU}

Hans Raj College, Delhi-7, India

Received September 13, 1971

During the course of investigations on the iron(III) complexes of 3-nitroso-4-hydroxycoumarin we found that this compound can be successfully employed as indicator in the EDTA titration of iron(III). The optimum conditions worked out are incorporated in the following procedure.

Adjust the $\mathrm{pH}$ of the acidie sample solution with $1-70 \mathrm{mg}$ of $\mathrm{Fe}$ (III) to about 2 (optimum range $1.5-4.0$ ) using $\mathrm{NH}_{4} \mathrm{OH}$ and add $10 \mathrm{ml}$ of hydrochloric acid/sodium acetate buffer (1 M; $\mathrm{pH} 2$ ). Add 5-10 drops of $0.5 \%$ ethanolic solution of 3-nitroso-4-hydroxycoumarin, dilute to about $100 \mathrm{ml}$ and titrate with $0.02 \mathrm{M}$ or $0.05 \mathrm{M}$ EDTA solution up to a sharp colour change from blue to colourless. With higher concentrations of $\mathrm{Fe}$ (III) the end-point is indicated by the disappearance of the last traces of a greenish blue colour resulting in the formation of yellow solutions.

With very large concentrations of $\mathrm{Fe}$ (III) the titrations become erratic presumably because of the larger concentrations of acetate required to keep $\mathrm{Fe}(\mathrm{III})$ in solution.

The following ions interfere seriously: cyanide, thiocyanate, oxalate, vanadium(IV and V), bismuth(III), nickel, cobalt, copper and palladium(II).

The following ions can be tolerated in the amounts given in parentheses (together with masking agent, if 